\title{
Oor Calvyn se siening van die nagmaal ${ }^{1}$
}

NGTT DEEL 55, NO 1, 2014

\section{Smit, D J}

Sistematiese Teologie

Universiteit Stellenbosch

\section{ABSTRACT}

\section{Calvin's views on the Lord's Supper}

During the Calvin commemoration of 2009, the question was often asked whether his views on the Lord's Supper still hold ecumenical potential for today. A first section deals with the controversial question where exactly Calvin's views on the Lord's Supper should be found and how it should be described. In an attempt to respond to this question still challenging contemporary scholarship, a second section attempts to provide an answer in terms of Calvin's comprehensive understanding of the presence of Christ. His views regarding the Supper can only be construed as integral part of his views regarding Christ's presence. Five forms of Christ's presence are distinguished in Calvin's thought, namely a living presence, a spiritual presence, a sacramental presence, a eucharistic presence and an ecclesiological presence. A final section considers the contemporary ecumenical question whether these views could be appropriated today, in the light of several serious obstacles.

1 Hierdie voordrag is oorspronklik op uitnodiging voorberei vir'n ekumeniese konsultasie in 2010 aan die Ekumeniese Navorsingsentrum van die Lutherse Wêreldfederasie in Strasbourg, wat dié geleentheid aangebied het saam met die ekumeniese navorsingssentra in Paderborn en Bochum. Die bedoeling was om 'n evaluering te maak van die wêreldwye verrigtinge tydens die Calvyn-herdenking in 2009 met die oog op die vraag welke ekumeniese potensiaal in Calvyn se werk en nalatenskap sigbaar geword het. Die spesifieke versoek was gevolglik om die ekumeniese potensiaal van sy nagmaalsbeskouing te ondersoek en te vra of enige konkrete ekumeniese voorstelle dalk daarin verskuil lê. 


\section{NUWE INSIGTE UIT DIE CALVYN-JAAR?}

In 2009 het die wêreldwye herdenking van Calvyn se geboorte 500 jaar tevore 'n nuwe belangstelling in en bewustheid van sy lewe en werk in sowel Gereformeerde as in breër ekumeniese kringe gebring; baie referate, studies en publikasies het ontstaan, en party sou selfs reken in sommige opsigte het nuwe kennis en insigte beskikbaar geraak; kortom, dit het klaarblyklik waardering by baie mense verhoog vir sy bydraes tot die kerk, samelewing en teologie, hetsy vir die eerste keer of deur 'n hernude waardering - maar bied dit alles vir ons konkrete en konstruktiewe ekumeniese voorstelle wat ons werklik sal help op die weg na beter gemeenskap en meer sigbare eenheid? En baie spesifiek, sou dit ook van toepassing wees op sy verstaan van die nagmaal wat in die sestiende eeu so 'n groot deel gevorm het van die debatte wat die kerk van Jesus Christus verdeel het? Het ons enige nuwe insigte verkry in sy siening van die sakramente, spesifiek die nagmaal - en sou sy sienings vandag as 'n betekenisvolle ekumeniese voorstel gesien kon word?

\section{CALVYN SE BEGRIP VAN DIE NAGMAAL?}

Wat presies was Calvyn se siening van die sakramente - en waar vind ons dit? Verskeie geleerdes het onlangs aangetoon dat Calvyn in werklikheid nie van die begin af al 'n uitgebreide en volledig ontwikkelde standpunt oor die sakramente gehad het nie. ${ }^{2}$ So 'n interpretasie pas natuurlik baie goed in by Calvyn se eksplisiete

Enkele van die bydraes tydens daardie konsultasie het in 2012 as 'n bundel verskyn en die voordrag is ook daarin opgeneem as "... wahrhafte Teilhaber an der wahren Substanz des Leibes und Blutes Jesu Christi ...' - Calvins Verständnis von Eucharistie als ökumenisches Angebot?", in Johannes Calvin ökumenisch gelesen, A Birmele \& W Thönissen (Hrsg.), Evangelische Verlagsanstalt/Bonifatius, 2012, 71-96. Later in dieselfde jaar is, eweneens op uitnodiging, 'n openbare voordrag oor dieselfde tema in Heidelberg, Duitsland, gehou, as "The real presence of Christ? - Calvin's views on the Lord's Supper", tydens die 17. Heidelberger Ökumenisches Forum oor die tema Realpräsenz Jesus Christi im Abendmahl, 3./4. Dezember 2010, Ökumenisches Institut der Universität Heidelberg. 'n Verkorte weergawe van dié voordrag het verskyn as "Calvin on the real presence of Christ in the Lord's Supper", Lutheran Forum, Spring 2012, Vol. 46/1, 40-46. Die stuk is in Afrikaans deur Ria Smit vertaal.

2 Sien byvoorbeeld die nuttige opsomming in Janse, 2008a en die historiese beskrywing in Janse, 2008b, maar ook Davis, 1995, wat Janse beskryf as 'n "epoch-makende dissertasie". Party mense beskou Calvyn se vroeë beskrywing in sy Short Treatise on the Supper of our Lord (geskryf in 1540, gepubliseer in 1541), ander die Consensus Tigurinus, die ooreenkoms met die predikers van Zürich in 1549, en nog ander sy latere beskrywing in die 1559 Institusie, wat vyf jaar voor sy dood gepubliseer is, as 
begrip van lering en onderrig, by sy doelbewus retoriese teologie en sy bewussyn van en aanvoeling vir gehoor en historiese konteks, en ook inderdaad by sy ekumeniese passie en besorgdheid, naamlik om eenstemmigheid te vind, konsensus, harmonie, sigbare eenheid - en in die proses plooibaar, oop, aangenaam, selfs wanneer nodig stilswyend te wees. Sulke historiese beskrywings van sy veranderende uitdrukkings en beklemtonings illustreer immers juis Calvyn se verbintenis aan gemeenskap en die sigbare eenheid van die kerk dramaties, want hulle toon aan dat, deur sy standpunt oor die sakramente oor baie jare in verskillende kontekste en gesprekke te formuleer - soms in debat, selfs konflik en verdeeldheid - was hy meer as gewillig om tegemoet te kom, om kompromieë aan te gaan, om te aanvaar en te ondersteun en agterna heelhartig formulerings te verdedig wat nie sy eie keuse sou wees nie, omdat hy oortuig was dat ook die sluit van ooreenkomste rakende formulerings oor die sakramente die gawe van die eenheid van die kerk sigbaar moes laat blyk. ${ }^{3}$

die mees verteenwoordigende uitdrukking van sy standpunt oor die sakramente. Janse stem nie met hierdie pogings saam nie en demonstreer oortuigend dat Calvyn hom op baie komplekse en diverse maniere kon uitdruk oor die sakramente, afhangende van sy gespreksgenote en lesers op 'n bepaalde tydstip (Janse, 2008a, 387).

3 Volgens Janse se leersame en goed-gedokumenteerde beskrywing is dit nuttig om ten minste drie fases in Calvyn se manier van dink oor en beskrywing van die sakramente te onderskei. Hy noem die eerste fase tussen 1536 en 1537 'n tydperk van Zwinglianisering. In verskeie bronne uit dié tyd kom Calvyn se formulerings naby die standpunte van die Zürich-teoloë, deur byvoorbeeld die herdenkings- en ekklesiologies-etiese aspekte van die nagmaal te beklemtoon. In 'n tweede fase, tussen 1537 en 1548, sien Calvyn die moontlikheid dat konsensus met die Lutherane sou kon realiseer, en daarom probeer hy - in 'n hele reeks publikasies wat sy kommentaar op 1 Korinthiërs insluit (in 1546) - die gawe-eienskap van die nagmaal beklemtoon en die werklikheid van die teenwoordigheid van Christus en van die eenheid met Christus, en onderbeklemtoon hy die herdenkings- en ekklesiologies-etiese aspekte. Nou beklemtoon hy dat deelname nie slegs met die gawes van Christus is nie maar met Christus self, dat die herdenking nie bloot as noëties gesien moet word nie, dat die teken (die werklike eet en drink van werklike brood en wyn) nie geskei moet word van die aangeduide saak (te wete geestelike verlossing) nie, dat die sakramentele eet en drink nie leeg en betekenisloos gemaak moet word (as bloot "bare and empty signs") nie, dat die sakrament ' $n$ instrumentele aard het deurdat iets waarlik en werklik gebeur - deurdat gelowiges ingelyf word, verenig word, geïnkorporeer word, hulle neem deel, hulle ontvang Christus self, Christus woon in hulle, ensovoorts. Natuurlik behou Calvyn nog steeds die sentrale besorgdhede van sy vroeëre standpunte, maar sy ekumeniese bedoeling en strategie is ook baie duidelik deurdat hy probeer om uitdrukkings en beklemtonings te vind wat die Lutherse teoloë uit die Duitse noorde sou gerusstel, en hy probeer om enige eksplisiete konfrontasie met Lutherse standpunte te vermy. As dit na 1549 duidelik word dat, ten spyte van al hierdie pogings, die Lutherane nie bereid was om die ooreenkoms te sluit en die 
Daar was natuurlik egter ook grense wat selfs Calvyn nie bereid was om oor te steek nie, daar was formulerings wat hy nie kon aanvaar of waartoe hy nie kon instem nie (en hy kon dit, soos dit destyds gebruiklik was, soms in baie ruwe terme uitdruk), daar was sieninge oor die sakramente (beide die doop en die nagmaal) wat hy nie kon akkommodeer nie, en in daardie sin is dit sekerlik óók moontlik om wel te praat van Calvyn se standpunte oor die sakrament - dit was 'n oop en plooibare siening, maar binne besliste grense. Daarom het baie geleerdes inderdaad 'n saak daarvoor uitgemaak dat Calvyn se standpunte oor die sakramente, wat die nagmaal insluit, nie gesien moet word as bloot die resultaat van (strategiese en kerk-politieke) pogings om konsensus te bereik nie, selfs om kompromieë tussen uiteenlopende standpunte aan te gaan ter wille van eenheid nie, maar eerder as die gevolg van sy eie teologiese oortuigings, wat konsekwent was in terme van sy eie verstaan van die evangelie self. ${ }^{4}$

Consensus Tigurinus te aanvaar nie, lyk dit asof Calvyn weer eens sy fokus verskuif, in 'n derde fase. In die 1550's behou hy daarom steeds sy vroeëre standpunte, maar nou versterk hy byvoorbeeld weer eens die beklemtoning van die rol van die Gees en ook die ekklesiologies-etiese aspekte van die nagmaal. Nadat hy in die 1540's die werklike eenheid met Christus beklemtoon het (met die oog op die Lutherane), beklemtoon hy nou met ander woorde weer eens die sigbare eenheid met mekaar in die 1550's (met die oog daarop om die konsensus wat hy alreeds met Zürich bereik het, te behou en te versterk). Baie van die bekende en aangrypende aanhalings oor die sigbare eenheid van die kerk en die belangrikheid van wedersydse liefde binne die kerk - as saam ingesluit in Christus behoort gelowiges ook onderling die gemeenskap te beoefen wat die nagmaal as band van liefde werklik tussen hulle tot stand bring - kom gevolglik uit hierdie tydperk, insluitende Calvyn se (teen hierdie tyd baie uitvoerige) besprekings van die sakramente in die Institusie van 1559. Janse verwys trouens na 'n vierde fase, ná 1560, toe nuwe moontlikhede vir toenadering tot die Lutherane in Noord-Duitsland ontstaan het en "Calvyn teruggekeer het na sy Luther-vriendelike deuntjie van die 1540's” (Janse, 2008b).

4 Twee voorbeelde is voldoende. In haar baie leersame historiese studie oor The Eucharist in the Reformation (2006), ontwikkel Lee Palmer Wandel hierdie standpunt as haar tese. Sy verduidelik Calvyn se sienings van die nagmaal as die koherente en konsekwente kulminasie van sy hele projek, sy "epistemologiese onderneming", in haar eie woorde. Sy beskou dit as 'n mislukking in die bestudering van Calvyn dat slegs weinig geleerdes sy standpunte eintlik vanuit hierdie perspektief verduidelik het, en haar eie werk is daarom juis 'n poging om so 'n noukeurige lees van die Institusie te bied wat tot 'n nuwe waardering by geleerdes sal lei vir die plek en funksie van sy standpunte oor die nagmaal binne Calvyn se projek as geheel. "Calvin situated his own fullest formulation within the epistemological enterprise of the Institutes. As such, Calvin's conceptualization of the Eucharist exists in important ways autonomous of either Zwingli or Luther ... To this day, few have approached Calvin's conceptualization of the Eucharist, as in fact he intended, through the entire project of the Institutes, in which he sought to teach the faithful how to see the place of the Eucharist in God's magnificent and ongoing project 
Wat was dan hierdie verstaan van die evangelie self? Baie mense het probeer om hierdie komplekse vraag - wat natuurlik ewigdurend en kontroversieel is - te beantwoord deur te wys op die belangrikheid van die teenwoordigheid van Christus vir Calvyn. Die Institusie as geheel is ontwerp om gelowiges te help om die teenwoordigheid van Christus waar te neem, sê Lee Palmer Wandel. ${ }^{5}$ Om Calvyn se lering van die nagmaal vanuit die perspektief van die evangelie te benader, beteken ook vir Brian Gerrish om dit te bedink onder opskrifte wat almal handel oor die teenwoordigheid van Christus. ${ }^{6}$ Om sy voorstel verder te ontwikkel, sal dit dalk nuttig wees om kortliks tussen vyf maniere van praat oor die teenwoordigheid van Christus te onderskei en om te onthou hoe hulle volgens Calvyn se siening met mekaar verband hou. ${ }^{7}$

of self-revelation" (Wandel, 2006, 143, 147; vir haar volledige bespreking, sien 139-207).

In baie van sy gedetailleerde en insiggewende historiese bydraes oor baie jare het Brian Gerrish alreeds soortgelyke aansprake gemaak. In sy baie bekende opstel oor "John Calvin on the Lord's Supper" argumenteer hy byvoorbeeld: “(A) further note of warning has to be added by reason of the highly controversial nature of eucharistic questions. During the sixteenth century, each party's teaching on the Lord's Supper was developed dialectically in conversation with rival interpretations; and conversation sometimes became bitter polemic. Hence it may be hard to approach the historical questions unmoved by confessional commitments ... But ... Calvin's doctrine of the Lord's Supper is not adequately understood as, for example, a critique of medieval teachings; nor as a deviation from Lutheranism; nor as an attempt to formulate a compromise position among the various Protestant options. It would be easy to point at attempts at interpretation along these lines. But the only approach that does justice to Calvin himself must begin with his own chief theological concerns, and must ask how he saw the relationship between his gospel and his understanding of the Lord's Supper. Calvin's thought moves outwards from his apprehension of the gospel to his interpretation of the Eucharist. The inner coherence of his thinking is of far greater importance than its dialectical relationships, although no actual separation should or can be made between the inner and the outer concerns" (Gerrish, 1982, 107).

Konkreet beteken dit byvoorbeeld dat, volgens Gerrish, dit "geen sin het" om by die Marburg Colloquium te begin en dan die daaropvolgende nagmaalsdebatte waarin Calvyn betrokke was volgens daardie model te interpreteer nie. Hy spreek daarom sy "verbasing" uit oor hoe dikwels die debat van 1529 tussen Luther en Zwingli en hulle onderskeie volgelinge "geneem is as die paradigma vir die Luthers-Gereformeerde verskille oor die nagmaal" (Gerrish, 1982, 107).

5 Lee Palmer Wandel, The Eucharist in the Reformation, 147.

6 Brian Gerrish, The Old Protestantism and the New, 107-117; sien ook sy Grace and Gratitude, veral 1-20.

7 In die spesifieke opstel gebruik Gerrish eintlik net vier opskrifte, naamlik die sentraliteit van Christus se teenwoordigheid, die manier waarop Christus teenwoordig is, die 
Eerstens gaan die evangelie vir Calvyn oor die lewende en persoonlike aanwesigheid van Jesus Christus. Gelowiges is met Christus verenig, hulle het gemeenskap met Christus, hulle is geïnkorporeer in Christus. Tweedens is die aard van sy teenwoordigheid geestelik, dit gebeur deur die Woord en Gees en daarom deur geloof. Derdens, onafskeidbaar van hierdie geestelike teenwoordigheid is ook Christus se sakramentele aanwesigheid, die werklike en ware teenwoordigheid van dit wat deur die teken aangedui word. Vierdens, onafskeidbaar van die sakramentele teenwoordigheid is daarom ook Christus se eucharistiese teenwoordigheid en die gelowiges se ware deelname aan die egte substansie van sy liggaam en bloed. Laastens loop dit uit in 'n ekklesiologiese teenwoordigheid van Christus in die kerk as sy liggaam en in die dankbare en liefdevolle lewe van hulle wat nie aan hulleself behoort nie, maar aan Christus.

Dit is teen die agtergrond van so'n komplekse begrip van Christus se teenwoordigheid - lewend, geestelik, sakramenteel, eucharisties, ekklesiologies - dat die kenmerke van Calvyn se eie standpunte hopelik duidelik sal word, ook die interne konsekwentheid van sy verstaan van die evangelie, sy vryheid wat betref taalgebruik en verskillende maniere om oor hierdie teenwoordigheid te praat, maar ook die beperkinge op denkwyses en uitdrukking wat hy as moontlik en legitiem beskou het. In die proses sal sy standpunte oor baie van die bekende kontroverse in sy tyd hopelik duideliker word, en die vraag of sy standpunte as 'n kontemporêre ekumeniese voorstel gesien kan word, weer gestel kan word.

\section{Christus se lewende teenwoordigheid}

In'n belangrike monografie het die bekende Calvyn-geleerde Charles Partee onlangs die teologie van Johannes Calvyn ontleed met die stelling dat "eenheid met Christus" gesien kan word as die integrerende idee van die Institusie as geheel, 'n aanspraak wat hy dan verdedig teen baie uiteenlopende stemme in die Noord-Amerikaanse vakwêreld. ${ }^{8}$ In 'n soortgelyke trant het die vermaarde Reformasie-geleerde Randall Zachmann 'n kort maar helder oorsig van die struktuur van Calvyn se denke

teenwoordigheid in die nagmaal en uiteindelik Calvyn en die Gereformeerde lering van die nagmaal (Gerrish 1982, 107-117), maar die volgende uiteensetting sal ook op sommige van sy ander geskrifte steun, waarin meerdere aspekte ter sprake kom. Vir 'n onlangse en baie nuttige bundel opstelle oor die teenwoordigheid van Christus, sien ook Thomas J Davis, This is my body. The presence of Christ in Reformation thought, 2008.

8 Charles Partee, The theology of John Calvin (2008). 
gepubliseer wat hy beskryf as "communio cum Christo". 9 Kortom, vir baie is hierdie tema van die sogenaamde mistiese eenheid van gelowiges met Christus sentraal tot Calvyn se verstaan van die evangelie. Gelowiges het gemeenskap met Christus, hulle deel in Christus, hulle is verenig met Christus, hulle is een met Christus - en vir Calvyn is dit die hart van die Christelike geloof en lewe en ook die hart van die kerk. Gelowiges is een met Christus en behoort aan Christus want Christus het hulle ingelyf in homself, omdat Christus in hulle woon en hulle in Christus, omdat hulle deel het aan Christus, deel in Christus, gemeenskap het met Christus. "Dit is die doel van die evangelie", sê Calvyn, "dat Christus ons s'n moet word, en dat ons ingelyf moet wees in sy liggaam." ${ }^{10}$ Gerrish onderstreep dat dit van deurslaggewende belang is om te sien dat Calvyn praat oor die "teenwoordigheid van Christus in die hier en nou". Volgens hom kulmineer Calvyn se denke in die "idee van 'n 'geheime gemeenskap' waardeur Christus-vir-ons Christus-in-ons word”. Dit is 'n lewende, persoonlike ervaring en gemeenskap - met die belangrike implikasie dat "ons alreeds die eucharistiese taal gebruik nog voor ons direk oor die nagmaal begin praat". Terselfdertyd is party van die tradisionele teenstrydighede oor Calvyn se standpunte oor die nagmaal natuurlik alreeds hier aangedui, deur sy Christologiese oortuigings

9 Randall Zachmann, "Communio cum Christo" (2008). Baie ander studies wat aspekte van hierdie tema van eenheid met Christus behandel, het verskyn, en sommige daarvan word as baanbrekerswerk beskou. Die Rooms-Katolieke teoloog Dennis Tamburello het byvoorbeeld 'n bydrae gelewer wat dikwels bespreek word en waarin die vraag oordink word of en op watter manier, indien wel, Calvyn se siening van gelowiges se eenheid met Christus beïnvloed is deur die mistisisme van Bernard van Clairvaux (Tamburello, Union with Christ. John Calvin and the mysticism of St. Bernard, 1994). Todd Billings, wat die Templeton Prys vir Teologiese Belowendheid ontvang het vir sy doktorale proefskrif getiteld Calvin, participation, and the gift: The activity of believers in union with Christ (2007), span die baie hedendaagse teoloë in wat die begrippe gawe ("gift"), ruil ("exchange") en deelname ("participation") ondersoek om die verhouding tussen God en menslike aktiwiteit te beskryf en wat in dié proses dikwels Calvyn as 'n negatiewe teenhanger gebruik en sy "ontoereikende teologie van menslike resiprositeit" kritiseer. Billings verwerp hierdie soort kritiek deur die tema van "deelname in Christus" te volg soos dit vanaf Calvyn se vroegste werk in 1536 ontwikkel het tot in sy laaste traktate in 1561 , en bied in die proses 'n nuwe en nuttige invalshoek tot die tema van eenheid met Christus in Calvyn se denke.

10 Calvyn in 'n brief aan Peter Martyr op 8 Augustus 1555, wat dikwels deur Gerrish gebruik word om hierdie Christologiese teenwoordigheid in Calvyn te verduidelik, byvoorbeeld in Grace and Gratitude, 128-133; ook in The Old Protestantism and the New, 108-109. 
en derhalwe sy voorveronderstellings, voordat die tema van die nagmaal selfs eksplisiet genoem is. ${ }^{11}$

\section{Christus se geestelike teenwoordigheid}

"If there lies at the heart of Calvin's gospel the thought of Christ's real presence or his real self-communication, the next question concerns the manner of that presence: How does Christ communicate himself? What is the vehicle of the real presence?"12 Volgens Calvyn se verstaan van die evangelie sou hierdie vraag beantwoord kon word vanuit drie verskillende perspektiewe, sê Gerrish, en hy redeneer dat dit noodsaaklik is om die drie antwoorde bymekaar te hou om 'n billike en geskikte beskrywing van Calvyn se lering te gee. Vanuit die gesigshoek van die menslike persoon, sê Gerrish, is Christus aanwesig in die daad van geloof. Vanuit die perspektief van die goddelike persoon is Christus aanwesig deur die aktiwiteit van die Heilige Gees. As 'n mens praat van eksterne middele, is Christus aanwesig deur die Woord. Hierdie drie, naamlik geloof, Gees en Woord, moet nie geskei word van mekaar as ons Calvyn probeer verstaan nie, sê hy. ${ }^{13}$ Dit is teen hierdie agtergrond dat baie van die bekende uitdrukkings van Calvyn verstaan moet word, wat soms die rol van geloof beklemtoon as dat dit Christus aantrek en ingelyf is in Hom - die aktiewe deelname en deelnemende rol van gelowiges wat opnuut deur Billings ondersoek is; wat soms die rol van die Gees beklemtoon wat die gawe van geloof oor ons uitstort, soms die rol van die Woord of evangelie beklemtoon as die instrument of middel waardeur die Gees werk deur Christus aanwesig en werklik in ons te mak. Dit is natuurlik ook hier waar sommige tradisionele teenstrydighede opgeduik het, byvoorbeeld wat Calvyn se verstaan van die geestelike teenwoordigheid betref en sy standpunte rondom die verhouding tussen geloof, Gees, Woord - en sakrament.

\section{Christus se sakramentele teenwoordigheid}

Want, waar pas die sakramente in? vra Gerrish, en antwoord dat vir Calvyn, in navolging van Augustinus se verbum visibile, dit'n ander vorm van die Woord is, nou nie gesproke en gehoor nie, maar sigbaar. "Die identiteit van inhoud" - sê Gerrish - "tussen die sakrament en die verkondiging bied vir Calvyn die leidraad om baie

11 Daar kan byvoorbeeld melding gemaak word van sy standpunte oor die hemelvaart, die sogenaamde extra calvinisticum, die lokaliteit van Christus, die debatte oor die gekruisigde en verheerlikte Christus, sy menslike natuur en liggaam, en die kontroversie rondom sy sogenaamde menslike alomteenwoordigheid.

12 Gerrish, The Old Protestantism and the New, 109.

13 Gerrish, The Old Protestantism and the New, 109-110. 
van die ou vrae oor hoe 'n sakrament werk, te beantwoord". Die sakramente is seëls van die verkondiging, hulle ondersteun ook die geloof, hulle is ook instrumente van die Gees - "the efficacy of the sacraments lies in that triple conjunction of Word, Spirit, and faith. Any attempt to break the unity of the conjunction can only lead to misunderstanding." ${ }^{14}$ Omdat die sakramente, net soos die Woord, Jesus aan ons aanbied en voorstel, is hulle ook die "medium van Christus se self-kommunikasie, van die werklike teenwoordigheid". Volgens Gerrish stam die gewilde misverstand "dat die sakramente vir Calvyn 'n suiwer simboliese en pedagogiese funksie het" uit "alleen maar die mees perverse verkeerd-lees van die bronne". Woord en sakrament het sekerlik 'n pedagogiese funksie, maar dit mak hulle "nie minder middele vir Christus se self-aanbieding nie" - hulle is ook "werklike middele van genade waardeur die ding wat gesimboliseer word, gekommunikeer word". ${ }^{15}$ Vir Calvyn se verstaan van die sakramente is dit van die allergrootste belang. Volgens Gerrish is dit "feitlik te veel om te beweer dat Calvyn se hele sakramentele teologie implisiet binne sy lering van sakramentele tekens lê (wat hy natuurlik aan Augustinus ontleen het)" ${ }^{16}$ Die teken en die ding wat aangedui word kan onderskei word, maar nie geskei word nie. ${ }^{17}$ Waar die teken is, daar is die werklikheid ook - en omdat Christus self die werklikheid is, die saak of die inhoud van die sakramente, is die tekens niks minder nie as beloftes van Christus se ware teenwoordigheid. "Hulle is middele waardeur Christus sy teenwoordigheid aan sy mense in werking stel. Die teken kan nie die werklikheid wees of dit word nie, maar dit is ook nie die simbool van 'n afwesige werklikheid nie." ${ }^{18}$ Dit is op die basis van hierdie verstaan van Christus se sakramentele aanwesigheid dat Calvyn oop en plooibaar sou wees om verskillende maniere van praat te akkommodeer en terselfdertyd so ernstig om uitdrukkingsen denkvorme te verwerp wat vir hom gelyk het of hulle op teenstrydige begrippe gebaseer is. Dit sou natuurlik in sy standpunte oor die nagmaal aangetoon kon word.

\section{Christus se eucharistiese teenwoordigheid}

Toe die idee van Christus se lewende teenwoordigheid wat deur die Gees bewerk word deur die Woord (en die sakramente) eers as die hart van Calvyn se evangelie

14 Gerrish, The Old Protestantism and the New, 110.

15 Sien byvoorbeeld Plasger, Johannes Calvins Theologie - Eine Einführung, 2008, waar die sakramente bespreek word onder die opskrif "Goddelike algehele pedagogiek sakramente as hulpmiddels", 117-125.

16 Gerrish, The Old Protestantism and the New, 110-111.

17 Calvyn pas die taal van die Christologiese formules van Chalcedon toe op die sakramente.

18 Gerrish, The Old Protestantism and the New, 111. 
daargestel is, was sy lering van die eucharistiese teenwoordigheid reeds halfpad aangebied, sê Gerrish. ${ }^{19}$ Die gemeenskap van gelowiges met Christus is nie heel en volmaak van die begin af nie, maar is onderworpe aan groei, wisselvallighede en hindernisse, dit het voller inbesitname en genot nodig, dit het voeding nodig, handhawing, verdieping, toename, en dit is binne hierdie perspektief dat Calvyn die rol van die nagmaal in die lewe van die kerk sien. ${ }^{20}$ In hierdie opsig wys Calvyn 'n diep agting, 'n spesiale ontsag, vir die sakrament van die nagmaal. ${ }^{21}$ Per slot van rekening "oorheers" die persoon van die lewende Christus sy denke oor die nagmaal. Vir hom bly hierdie teenwoordigheid van die Here uiteindelik "n misterie wat slegs aanbid kan word en nie vasgevang kan word in teologiese verklarings nie" - sodat hy tevrede is om verwonderd te staan voor dit wat hy nie kan verstaan nie..$^{22}$ Nogtans beweer Gerrish dat die "hooftrekke" van Calvyn se interpretasie van die nagmaal "maklik herken" kan word en bied hy op 'n hulpvaardige wyse so 'n opsomming in die vorm van sewe stellings wat die logika en innerlike konsekwentheid van Calvyn se standpunte illustreer: ${ }^{23}$

Eerstens is die nagmaal 'n gawe. Dit is basies aan die hele oriëntasie van Calvyn se denke oor die sakrament, sê hy. Hier "skei Calvyn weë met Zwingli terselfdertyd as wat hy in onversetlike teenstand teen Rome staan". ${ }^{24}$ God skenk - die bewering wat Calvyn van Zwingli skei; ${ }^{25}$ en God skenk - mense gee nie, ons ontvang, téén Rome, volgens Calvyn se begrip. Tweedens is die gawe Jesus Christus self, iets wat Calvyn nooit moeg word om te sê nie - nie slegs die weldade van Christus nie (soos wat

19 Gerrish, The Old Protestantism and the New, 111.

20 Sien ook Gerrish se hele Grace and Gratitude, waar die tema van die heilige feesmaal en van voeding en voedsel 'n sentrale rol speel.

21 "The special reverence Calvin felt for the sacrament is too plain to be overlooked; nowhere is the man's piety more clearly disclosed," Gerrish, The Old Testament and the New, 112.

22 Gerrish, The Old Testament and the New, 112. Dit is weer eens 'n verwysing na Calvyn se brief aan Peter Martyr, maar ook na Calvyn se woorde en instelling in die Institusie IV/17.7, 10, 32.

23 Gerrish, The Old Protestantism and the New, 112-115. In sy hoofstuk in Grace and Gratitude oor die nagmaal, wat die "The Eucharistic Offering" genoem word, bespreek hy net die eerste ses stellings, maar ontwikkel dan uitvoerig die sewende stelling oor dankbaarheid na die einde van dieselfde hoofstuk toe, 145-156.

24 Gerrish, The Old Protestantism and the New, 112.

25 Die nagmaal is vir Calvyn nie bloot 'n geleentheid vir dankbare besinning nie. Die nagmaal is 'n gawe, dit herinner ons nie net bloot aan 'n gawe nie, Gerrish, The Old Protestantism and the New, 113. 
hy dikwels uitgebeeld word), nie slegs die goddelikheid van Christus nie (waarvan hy dikwels beskuldig word), maar die hele Christus inderdaad, met sy liggaam en bloed, met sy menslikheid, met sy vlees ${ }^{26}$ met hom as geheel, "voed ons siele aan sy liggaam en bloed" ${ }^{27}$ as werklike voedsel, is ons waarlik deelnemers aan "die werklike substansie van die liggaam en bloed van Jesus Christus". ${ }^{28}$ Derdens word die gawe deur die tekens gegee - weer eens teen sowel Zwingli as Rome, wat albei die aard van die teken volgens hom verdraai het. Rome omskep die teken in die ding wat dit aandui. Zwingli skei teken en werklikheid van mekaar. Vir Calvyn "is" die tekens dit wat hulle "verteenwoordig": hulle is nie oop en leeg nie, maar "verbind met die werklikheid wat hulle aandui". ${ }^{29}$ Vierdens word die gawe geskenk deur die Heilige Gees, en is hulle middele of instrumente van die Gees wat die "eenheidsband" tussen gelowiges en die werklike, lewegewende vlees van Christus is. Die taal van "geestelike teenwoordigheid", "geestelike voedsel", "geestelike drank" of "geestelike eet" moet daarom nie gesien word as dat Christus "slegs in gees teenwoordig is of slegs in die verbeelding van die gelowiges nie", sê Gerrish - hoewel albei hierdie standpunte verkeerdelik aan Calvyn toegeskryf is ten spyte van sy eksplisiete en konsekwente ontkenning in al sy belangrike werke oor die nagmaal. ${ }^{30}$ Vyfdens word hierdie gawe gegee aan almal wat deelneem, vroom en oneerbiedig, gelowiges en ongelowiges. ${ }^{31}$ Die waarheid en effektiwiteit van die sakrament bly onverminderd, sê Calvyn; as sommiges uit die hoogte die gawe weier en verwerp, is dit "die volheid van die sakrament wat die wêreld in sy geheel nie kan skend nie: dat die vlees en bloed van Christus nie minder werklik aan die onwaardiges gegee word as aan God se verkose gelowiges nie". ${ }^{32}$ In die sesde plek word die weldaad van die gawe in geloof ontvang, teen enige onpersoonlike verstaan van die sakramentele effektiwiteit in. Vir Calvyn is die sakramentele Woord wat die sakrament vergesel volgens Gerrish "nie 'n beswering nie, maar 'n belofte" en "die gebeurtenis waarin die werklike teenwoordigheid geskied is nie die inseëning van die elemente nie, maar

26 Gerrish, The Old Protestantism and the New, 113.

27 Calvyn, "Short Treatise on the Lord's Supper", Tracts and Treatises, Vol. II, 170.

28 "In his Sacred Supper (Christ) bids me take, eat, and drink his body and blood under the symbols of bread and wine. I do not doubt that he himself truly presents them, and that I receive them," Institusie IV/17.32. Oor die begrippe van nuttiging en deelname, sien veral Billings, Calvin, participation and the gift: The activity of believers in union with Christ.

29 Gerrish, The Old Protestantism and the New, 113.

30 Gerrish, The Old Protestantism and the New, 113.

31 Gerrish, The Old Protestantism and the New, 114.

32 Calvyn, Institusie IV/17.33. 
die ontvang van die elemente in geloof onder die werking van die Heilige Gees". ${ }^{33}$ Hierdie ontvangs kan daarom ook plaasvind in die lewe van die gelowige selfs ná die sakrament self. In die sewende plek bewerk die gawe dankbaarheid. Hoewel die sakrament in eintlike sin die werk van God is, is dit in breër liturgiese sin ook die werk van die kerk. ${ }^{34}$ Nie alleen gee dié insig betekenis aan die term "eucharistie" $n^{2} e^{35}$ - as die kerk se danksegging vir die gawe wat gegee word - maar dit maak dit ook betekenisvol en eintlik belangrik om te praat van "offer", hoewel nié in die sin van 'n versoenende offer nie. 'n Eucharistiese offer, in die sin van 'n "lofoffer," 'n "eucharistiese offerande," 'n "dankbare selfopoffering deur die heilige priesterdom", vorm 'n onlosmaaklike deel van die liturgie en van die deelname en respons van die gemeente op die gawe.

Kortom, die nagmaal is 'n gawe - die gawe van die lewende Jesus Christus self, wat gegee is deur die tekens, deur die Gees, aan almal wat deelneem, ontvang in geloof en wat dankbaarheid en dankbare selfopoffering bewerk. Dit sou waarskynlik dus Calvyn se "ekumeniese voorstel" aangaande die nagmaal kon wees.

\section{Christus se ekklesiologiese teenwoordigheid}

Dog waarom sou hy besorg wees oor 'n "ekumeniese voorstel"? Ander bydraes tydens hierdie konsultasie sal in groter besonderhede op sy ekklesiologie en sy ekumeniese passie wys, ${ }^{36}$ maar enige respons op dié vraag behoort ook sy standpunte oor die aard van die nagmaal en hierdie werklike en persoonlike teenwoordigheid van die lewende Christus te noem - geestelik, sakramenteel, eucharisties. Vir Calvyn lei hierdie werklike gemeenskap met Christus ook tot gemeenskap met mekaar. ${ }^{37}$

33 Gerrish, The Old Protestantism and the New, 114.

34 Gerrish, The Old Protestantism and the New, 114.

35 In die eerste uitgawe van die Institusie het Calvyn die terme "nagmaal" en "eucharistie" as sinonieme gebruik, maar later het hy "nagmaal" (soos ook in ander tale gebruiklik in avondmaal, laaste avondmaal, Supper, The Lord's Supper) verkies, omdat dit beter met sy siening van die sakrament ooreengekom het.

36 Sien Johannes Calvin ökumenisch gelesen, Hrsg. André Birmele \& Wolfgang Thönissen, Leipzig: Evangelische Verlagsanstalt, 2012, veral die bydraes van Michael Weinrich en Eva-Maria Faber.

37 In sy kommentaar op 1 Korinthiërs 10:16 verduidelik Calvyn byvoorbeeld: "Paul says, that the cup which has been blessed in this manner is koinonian - the communion of the blood of the Lord. It is asked, in what sense? It is true, that believers are united together by Christ's blood, so as to become one body. It is also true, that a unity of this kind is with propriety termed koinonia (communion). I make the same acknowledgement as to the bread, observing what Paul immediately adds, as it were, by way of explanation 
Deelname aan die liggaam van Christus bind gelowiges saam as die liggaam van Christus. Hulle eenheid met Christus maak hulle een met mekaar. Vir Calvyn kom die teenwoordigheid van Christus en die gemeenskap met Christus dus ook na vore in gelowiges wat mekaar aanvaar en met mekaar deel. Hierdie aspek, wat soms die "ekklesiologies-etiese" implikasies van die nagmaal genoem word, was vir hom van uiterste belang. Sy sterk taal in die 1559 Institusie maak dit baie duidelik. Alreeds in die openingsparagrawe van Boek $I V$, wanneer hy die kerk as gemeenskap van heiliges bespreek, onderstreep Calvyn die eenheid in gemeenskap en die noodsaaklikheid om hulle seëninge met mekaar te deel in wedersydse liefde. ${ }^{38}$ By die bespreking van die sakramente, veral die nagmaal in $I V / 17$, kom hierdie "ekklesiologies-etiese" beklemtonings baie passievol na vore. ${ }^{39}$ As sodanig maak hierdie "ekklesiologiese teenwoordigheid" van Christus dus 'n ekumeniese verlange vir sigbare eenheid

- that we all become one body, because we are together partakers of the same bread. But whence, I pray you, comes that koinonia between us, but from this, that we are united to Christ in such a way that we are flesh of his flesh, and bone of his bones (Ephesians 5:30)? For we must first of all be incorporated (so to speak) into Christ, that we may be united to each other. Paul is not disputing at present merely in reference to a mutual fellowship among people, but as to the spiritual union between Christ and believers" (effens verkort, en my beklemtoning).

38 "Moreover, this article of the Creed relates in some measure to the external Church, that every one of us must maintain brotherly and sisterly concord with all the children of God, give due authority to the Church, and, in short, conduct ourselves as sheep of the flock. And hence, the additional expression, the 'communion of saints'; for this clause must not be overlooked, as it admirably expresses the quality of the Church; just as if it had been said, that saints are united in the fellowship of Christ on this condition, that all the blessings which God bestows upon them are mutually communicated to each other ... For if they are truly persuaded that God is the common Father of them all, and Christ their common head, they cannot but be united together in brotherly and sisterly love, and mutually impart their blessings to each other" (IV/1.3, my beklemtoning). Volgens Peter Opitz (2009a) fokus die sentrale begrip agter Calvyn se standpunte oor kerklike bestuur en praktiese orde rondom die nagmaal, en is dit die motief vir versoening, en hy beweer dat dit ook waar is van Calvyn se sosiale etiek - en hy begrond dit op Calvyn se begrip van die communio sanctorum.

39 Gelowiges word gemaan tot liefdadigheid, vrede, harmonie en eenheid sonder verdeling. "The Lord intended it (this is my body, take eat) to be a kind of exhortation, that which no other could urge or animate us more strongly, both to purity and holiness of life, and also to charity, peace, and concord. For the Lord there communicates his body so that he may become altogether one with us, and we with him. Moreover, since he has only one body of which he makes us all to be partakers, we must necessarily, by this participation, all become one body. This unity is represented by the bread which is exhibited in the sacrament. As it is composed of many grains, so mingled together, that 
one cannot be distinguished from another; so ought our minds to be so cordially united, as not to allow of any dissension or division" (IV/17.38, my beklemtoning).

In die sterkste moontlike bewoording maak Calvyn gevolgtrekkings van hierdie eenheid met Christus in die nagmaal vir ons onderlinge eenheid. Vanweë dit wat gebeur in die sakrament kan ons eintlik nie langer Christus liefhê sonder om ons naaste lief te hê nie, en kan ons nie langer ons naaste kwaad aandoen sonder om vir Christus kwaad aan te doen nie. "We shall have profited admirably in the sacrament, if the thought shall have been impressed and engraved on our minds, that none of our brethren is hurt, despised, rejected, injured, or in any way offended, without our, at the same time, hurting, despising, and injuring Christ; that we cannot have dissension with our brethren, without at the same time dissenting from Christ; that we cannot love Christ without loving our brethren; that the same care we take of our own body we ought to take of that of our brethren, who are members of our body; that as no part of our body suffers pain without extending to the other parts, so every evil which our brothers and sisters suffer ought to excite our compassion. Wherefore Augustine not inappropriately often terms this sacrament the bond of charity. What stronger stimulus could be employed to excite mutual charity, than when Christ, presenting himself to us, not only invites us by his example to give and devote ourselves mutually to each other, but inasmuch as he makes himself common to all, also makes us all to be one in him" (IV/17.38, my beklemtoning).

In harde, byna siniese woorde beskryf Calvyn die aksies van gelowiges wat die nagmaal vier en voel dat Christus hulle lewe is en beweer dat hulle met Hom verenig is terwyl hulle geen ywer vir liefdadigheid toon nie en vervreemd en verwyderd van hulle naaste lewe - hulle lewer getuienis teen hulleself, sê hy, en hulle ruk en skeur Christus se liggaam aan stukke. "Moreover, as we see that this sacred bread of the Lord's Supper is spiritual food to the pious worshippers of God, on tasting which they feel that Christ is their life, are disposed to give thanks, and exhorted to mutual love; so, on the other hand, it is converted into the most noxious poison to all whom it does not nourish and confirm in the faith, nor urge to thanksgiving and charity. For people who, without any spark of faith, without any zeal for charity, rush forward like swine to seize the Lord's Supper, do not at all discern the Lord's body. For, inasmuch as they do not believe that body to be their life, they put every possible affront upon it, stripping it of all its dignity, and profane and contaminate it by so receiving; inasmuch as while alienated and estranged from their brethren, they dare to mingle the sacred symbol of Christ's body with their dissensions. No thanks to them if the body of Christ is not rent and torn to pieces. By this unworthy eating, they bring judgment on themselves. They bear witness against themselves. Being divided and separated by hatred and ill-will from their brethren, that is, from the members of Christ, they have no part in Christ, and yet they declare that the only safety is to communicate with Christ, and be united with him" (IV/17.40, my beklemtoning).

Dit is die rede, sê hy, waarom Paulus die kerk oproep om hulleself te ondersoek, of hulle inderdaad daarna strewe om hulle naaste as lede van hulle eie liggame te sien soos wat hulle deur Christus gesien word. "For this reason Paul commands everyone to examine themselves before they eat of that bread and drink of that cup. By this, as I understand it, he means that everyone should descend into themselves, and consider ... 
onafskeidbaar deel van enige ware begrip van en deelname aan die nagmaal. ${ }^{40}$ Die nagmaal self is 'n oproep om die gawe van eenheid te beliggaam, 'n oproep tot ekumeniese gemeenskap. Hierdie begrip mag daarom deel uitgemaak het van Calvyn se eie passie. Sy eie verstaan van die nagmaal laat geen ander respons toe nie - deelname in die lewende, persoonlike teenwoordigheid van Christus, Christus se geestelike, sakramentele en eucharistiese teenwoordigheid, roep om aktiewe en deernisvolle gemeenskap met mekaar in die liggaam van Christus, die kerk.

\section{'n EKUMENIESE VOORSTEL?}

Sou Calvyn se begrip van die nagmaal gevolglik gesien kon word as 'n konstruktiewe ekumeniese voorstel vir vandág? Per slot van rekening is die kort opsomming wat hier gegee is tog glad nie nuut nie? Miskien kan drie afsluitende opmerkings help om die vraag en ons besprekings verder te fokus.

Eerstens was dit in Calvyn se eie denke inderdáád reeds bewustelik óók 'n ekumeniese voorstel, in hedendaagse terminologie. Eva-Maria Faber het onlangs sowel Calvyn se teologiese nadenke oor die kerk as sy aandag aan die uiterlike ontwikkeling van die kerk, onderstreep, en aangetoon hoe sy diepe besorgdheid oor die eenheid van die kerk sowel teologies as prakties was. ${ }^{41}$ Daar kan geen twyfel bestaan omtrent sy hoop dat sy begrip van die nagmaal baie verskille en konflikte in die kerk van sy tyd kon en sou oorkom nie. Baie illustrasies sou gegee kon word van hierdie ekumeniese verlange, wat die manier waarop hy sy eie standpunte oor die nagmaal aanbied, insluit, byvoorbeeld in die Short Treatise on the Supper of our Lord (gepubliseer in 1541) en in die verskillende weergawes van die Institusie, sy positiewe

whether with zeal for purity and holiness they aspire to imitate Christ; whether, after his example, they are prepared to give themselves to their brethren. And to hold themselves in common with those with whom they have Christ in common; whether, as they themselves are regarded by Christ, they in their turn regard all their brethren as members of their own body, or like their members, desire to cherish, defend, and assist them, not that the duties of faith and charity can now be perfected in us, but because it behooves us to contend and seek, with all our heart, daily to increase our faith" (IV/17.40, my beklemtoning).

40 Die term is weer eens van Gerrish afkomstig. "This striking imagery of an 'ecclesial presence' of Christ, as we may call it, is a fundamental theme in Calvin's theology. Engrafting into Christ coincides so completely with entrance into the church that, when he writes of the body of Christ, it is not always possible to tell whether he means the glorified or the ecclesial body," Gerrish, Grace and Gratitude, 187-188.

41 Faber, "Mutual connectedness as a gift and a task: On John Calvin's understanding of the church", 2009. 
verhouding met Melanchton en sy pogings om Luther se eie goedkeuring te wen ${ }^{42}$ sy voortdurende pogings om wedersydse instemming met betrekking tot sakramente tussen die Switserse kerke te vind, ${ }^{43}$ sy positiewe houding jeens en ondertekening van die Augsburgse Konfessie, ${ }^{44}$ en 'n mens sou miskien selfs die driftige respons in sy later jare op sy Lutherse kritici kon interpreteer in terme van sy diepe teleurstelling dat hulle 'n moontlike ekumeniese ooreenkoms verbete teengestaan het, optrede wat natuurlik volgens hom onnodig was. ${ }^{45}$

Tweedens, aangesien sy toegewyde pogings in sy eie tyd onsuksesvol was, waarom sou hulle vandag enige belofte inhou? Weliswaar sou dit miskien moontlik kon wees omdat sommige van die baie misverstande, selfs karikature, met verloop van verwyder is? Miskien omdat daar vandag 'n dieper waardering vir sy standpunte is in Katolieke en Lutherse kringe? Miskien omdat die tye verander het, wat wydverspreide filosofiese en ander aannames insluit wat sommige van Calvyn se sienings meer aanvaarbaar maak vir sommige mense? Miskien het dit inderdaad vandag moontlik geword om die debatte van die Reformasie weer anders te voer, om ander lyne van skeiding te trek soos wat sommige juis voorstel, in navolging van Calvyn se standpunte oor die nagmaal ${ }^{26}$ Weer eens het party al reeds hierdie weg ingeslaan, en het hulle inderdaad geredeneer dat hy 'n konstruktiewe ekumeniese

42 Vir Calvyn en Melanchton, sien byvoorbeeld Mathison, Given for you, 69-73; vir Calvyn en Luther, sien byvoorbeeld Gerrish, "The Pathfinder: Calvin's image of Martin Luther", in Gerrish 1982, The Old Protestantism and the New, 27-50, en Oberman, The two Reformations.

43 Vir die teks en Calvyn se korrespondensie oor die hele proses, Calvyn, Tracts and Treatises, Volume II; vir'n insiggewende interpretasie, sien Paul Rorem, “The Consensus Tigurinus (1549): Did Calvin Compromise?”, ook onlangs Peter Opitz, Leben und Werk Johannes Calvins, 2009, veral 114-128; en Campi en Reich, Consensus Tigurinus. Heinrich Bullinger und Johannes Calvin über das Abendmahl, 2009.

44 Sien byvoorbeeld Nijenhuis, "Calvin and the Augsburg Confession", Gerrish, The Old Protestantism and the New, 248-263.

45 Vir Calvyn se response, sien Tracts and Treatises, Volume II; vir 'n bespreking en interpretasie, sien byvoorbeeld Steinmetz, "Calvin and his Lutheran critics", Gamble, “Calvin's controversies".

46 In 'n opstel getiteld "Sign and reality. The Lord's Supper in the Reformed Confessions, in The Old Protestantism and the New, 118-130, probeer Gerrish die lyne van skeiding op so 'n manier anders trek. As die belangrikste kwessie ter sprake die vraag was of die sakramente gawes of instrumente of middele van genade is, is die skeidslyn nie tussen Luthers en Gereformeerd nie, redeneer hy, maar binne die Gereformeerde gemeenskap self, met Luther aan die kant van Calvyn. Die gevolg is dat die debatte dikwels debatte oor minder sentrale kwessies was en nog steeds is. Hy kom tot die slotsom: "(T)he heart of Luther's own position seems clear: the sacrament is a gift, and the gift is Jesus 
voorstel bied, maar skynbaar ook sonder sukses. ${ }^{47}$ In 'n interessante opstel getiteld "Strasbourg Revisited: Reformed Perspectives on the Augsburg Confession", redeneer Brian Gerrish inderdaad dat die kerke van die Reformasie steeds terug kan gaan na "Strasbourg" om party van hulle verskille heel te maak, waarmee hy bedoel dat Calvyn se ekumeniese benadering tot die nagmaal wel sou kon dien as 'n weg vorentoe, maar hy voeg terselfdertyd by dat ander en miskien meer dringende skeidings ondertussen na vore getree het wat dwars déúr kerke van die Reformasie sny, en wat hulle dus op nuwe maniere onderling verdeel. ${ }^{48}$

Ander soek klaarblyklik op ander plekke na konstruktiewe ekumeniese voorstelle omtrent die nagmaal. Drie onlangse bydraes deur Gereformeerde teoloë sou ter illustrasie gebruik kon word. George Hunsiger, in The Eucharist and Ecumenism, en spesifiek ook in die eerste hoofstuk wat handel oor die "werklike teenwoordigheid", kyk skynbaar eerder na Oosters-Ortodokse standpunte in sy poging om 'n pad vorentoe te vind. ${ }^{49}$ Bram van de Beek, in God doet recht. Eschatologie als christologie, gaan skynbaar nog verder terug, na die vroeë kerk, vóór die teenstrydighede van die sestiende eeu die begrippe op maniere gevorm het wat nou lyk asof dit so moeilik is om ekumenies te oorkom. ${ }^{50}$ Michael Welker, in Was geht vor beim Abendmahl?, gaan skynbaar nóg selfs verder terug, na die evokatiewe bybelse beskrywings van die nag van verraad, om nuwe en konstruktiewe maniere te vind om te praat en te vier. ${ }^{51}$ Hoewel hulle almal nog steeds in die tradisie van Calvyn staan, suggereer hulle benaderings skynbaar dat dit moeilik mag wees om oplossings te vind vir die konflikte van die sestiende eeu binne daardie eeu self, selfs met Calvyn - per slot van rekening kon hulle nie hulle verskille tóé oorkom nie? Wat boonop van die konsensus, ook oor die ware teenwoordigheid van Christus, tussen Lutherse en Gereformeerde perspektiewe, wat alreeds in die $20^{\text {ste }}$ eeu bereik is - 'n konsensus waarvan Welker kan beweer dat juis die feit dat Calvyn se lering van die nagmaal 'n "bemiddelende posisie" gebied het "gehelp het om die kerke van die Reformasie

Christ. If that is what was dearest to Luther in his reverence for the sacrament, then the Calvinist confessions are on Luther's side of the line," 130.

47 Slegs een so 'n herinnering sal voldoende wees. G.C. Berkouwer, in sy bespreking "De tegenwoordigheid van Christus in het Avondmaal" in De Sacramenten, 294-326, bied 'n gedetailleerde argument waarin hy Calvyn se standpunte verdedig as 'n bydrae tot ekumeniese dialoog, en verwys uitvoerig na beskikbare literatuur waarin hierdie kwessies ook vroeër in die $20^{\text {ste }}$ eeu gedebatteer is.

48 Gerrisher, The Old Protestantism and the New, 248-263.

49 Hunsiger, The eucharist and ecumenism.

50 Abraham van de Beek, God doet recht. Eschatologie als christologie, 322-393.

51 Welker, What happens in holy communion? 
te verenig"? ${ }^{52}$ En wat van die ekumeniese stelling in die konsensus-dokument van "Faith and Order", naamlik Baptism, Eucharist and Ministry? Moet ons dan nog verder as dit soek, by Calvyn self?

Is dit ooit eintlik realisties om nuttige ekumeniese voorstelle omtrent die nagmaal te soek in die lig van die ontwikkelings in en sedert die tyd van die Reformasie, die verharding van standpunte en die vanselfsprekende aard van oortuigings en praktyke, van bediening en orde, van liturgiese tradisies en diepgewortelde maniere van aanbidding, van spiritualiteit en vroomheid - maar ook van maniere waarop ons ander sien? Lee Palmer Wandel se The Eucharist in the Reformation opper byvoorbeeld sulke skeptiese besorgdhede op 'n dramatiese wyse as sy doodeenvoudig die verhaal vertel van hoe hierdie uiteenlopende begrippe en praktyke ontwikkel het, en wat die kerk uitmekaar geskeur het. ${ }^{53}$ Dit opper natuurlik vrae oor ekumeniese visie en metodologie, oor wat ons hoop om te bereik, en wat ware gemeenskap vandag sou kon beteken en vra. Moet ons byvoorbeeld 'n leerstellige ooreenkoms nastrewe, of wedersydse erkenning, of iets anders?

Derdens is dit natuurlik so dat Calvyn self nie meer deel van die ekumeniese proses is nie, net Calviniste - en in baie opsigte stem hulle nie altyd saam met sy standpunte oor die nagmaal nie. Dit beteken dat, selfs al sou sy eie begrip meer konstruktief lyk vir ander ekumeniese gespreksgenote, hulle mag vind dat hulle in werklikheid te doen het met Gereformeerde gemeenskappe wat op baie maniere van Calvyn se standpunte afgewyk het. Weer eens is hierdie glad nie nuwe kennis nie; geleerdes het eintlik altyd van hierdie dikwels diep en radikale verskille geweet. Die relevansie is eenvoudig dat in 'n tyd waarin daar 'n nuwe bewustheid van en belangstelling in en selfs waardering vir Calvyn se siening oor die nagmaal is, hierdie standpunte dalk nie meer aanwesig is in werklike ekumeniese gesprekke nie. Daar is baie studies beskikbaar wat hierdie saak beredeneer. Keith A. Mathison bied byvoorbeeld 'n dramatiese en gedetailleerde beskrywing in Given for you. Reclaiming Calvin's doctrine of the Lord's Supper. Hy is skerp in sy oordeel, en dek die vroeë ontwikkelings in die 1500's en party van die vroeë belydenisse, latere ontwikkelings in die 1600's en 1700 's, en uiteindelik ontwikkelings in die 1800's en 1900's. ${ }^{54}$ Hy twyfel nie daaraan

52 Welker neem byvoorbeeld konsensus baie ernstig op. Hy redeneer dat dit gebou is op die "persoonlike teenwoordigheid" van Christus, en dat hierdie begrip dit moontlik maak om aan die kernbegrippe van albei tradisies vas te hou wat dikwels as onderling uitsluitend beskou is, sien 87-110, met die verwysing op 91.

53 Wandel, The Eucharist in the Reformation.

54 "Beza's scholasticism provides a bridge to the era of seventeenth-century Reformed orthodoxy, in which Calvin's doctrine began to be altered, but he himself did not participate in the alteration (62) ... Calvin's view (and even Bullinger's view) has 
dat die Gereformeerde kerk as geheel ver weg beweeg het van die eucharistiese lering van Calvyn nie, en baie geleerdes sal oor die algemeen saamstem met so 'n

actually faded out of the picture in Reformed churches over the last few centuries and been largely replaced by memorialist views (68) ... Calvin's doctrine was gradually rejected and replaced in the Reformed churches by views that sometimes go farther than Zwingli's in denying the true presence of Christ in the Supper and true communion with his flesh and blood (91) ... In the seventeenth and eighteenth centuries, there was a gradual move away from the eucharistic doctrine of John Calvin and the majority of the sixteenth-century Reformed confessions (93) ... In Turretin we see a noticeable shift away from the eucharistic doctrine of John Calvin and the late sixteenth-century Reformed confessions. While not abandoning it completely, there are significant alterations and omissions. The central theme of the union with Christ that is at the heart of Calvin's doctrine is only peripheral in Turretin. Turretin rejects Calvin's instrumentalism. He also rejects Calvin's concept of 'spiritual presence', replacing it with something that would be better termed a subjective 'mental presence.' This last idea seems to be one of the key ideas that have influenced Reformed sacramental theology to this day (119) ... When we turn to the writings of Reformed theologians in eighteenth-century New England, we begin to feel the full force of the shift away from Calvinist sacramental theology (122) ... By the time we reach mid-eighteenth-century New England, there is little left of the original eucharistic theology of Calvin because the emphases of Zwinglian theology have become dominant (128) ... By the beginning of the nineteenth century, the Calvinistic doctrine of the Lord's Supper had been largely abandoned in many segments of the Reformed church (129) ... (Charles Hodge) says that Calvin's doctrine (on the body and blood of Christ as received in the sacrament) is an 'uncongenial foreign element' that 'had no root in the system and could not live' (150) ... The sacramental controversy in the nineteenth century was not confined to the North. The Southern Presbyterian Church experienced it as well ... Robert Lewis Dabney was the most influential theologian in the Presbyterian Church in the U.S. in the latter half of the nineteenth century ... Daney explicitly rejected Calvin's doctrine of the Lord's Supper ... Dabney goes to great lengths to discredit Calvin's doctrine of the Eucharist ... (F)or Dabney, the 'eucharistic communion became little more than a didactic message designed to produce an inward comprehension of doctrinal truths with correspondingly appropriate emotional reactions' (156-158) ... (T)he gradual movement away from the Calvinist doctrine of the sixteenth century became an explicit rejection of that doctrine in the latter half of the nineteenth century (166) ... (T)he movement away from Calvin reached something of a zenith in the late nineteenth century ... There can be no doubt that the Reformed church as a whole has moved far from the eucharistic doctrine of Calvin and the Reformed church of the sixteenth century (76)," Mathison, Given for you. 
standpunt. ${ }^{55}$ Dit is sekerlik baie wydverspreid waar van populêre aanbidding en vroomheid in Gereformeerde en Presbiteriaanse gemeentes. ${ }^{56}$

Miskien sou 'n mens selfs kon redeneer, op grond van die bogenoemde vyf vorme van teenwoordigheid van Christus by Calvyn, dat die Gereformeerde geloof dikwels ál vyf uit die oog verloor het - dat Christus se lewende en persoonlike teenwoordigheid meermale verruil word vir idees oor Christus; dat Christus se geestelike teenwoordigheid vervang is deur slegs ons subjektiewe gedagtes en gevoelens; dat Christus se sakramentele teenwoordigheid verminder word tot blote herinnerings; dat Christus se eucharistiese teenwoordigheid verwar word met bloot ons eie mentale aktiwiteite; dat Christus se ekklesiologiese teenwoordigheid verlore gaan in eintlik slegs'n genootskap van eenders-denkende individue. ${ }^{57}$ Hoewel daar'n

55 Die komplekse verhouding tussen Calvyn en Calvinisme wat alreeds in sy eie tyd, maar meer nog in latere ontwikkelings bestaan het, is natuurlik 'n belangrike tema op sy eie. Geleerdes stem nie saam oor sy standpunte omtrent die nagmaal nie, en dit begin alreeds met uiteenlopende oordele omtrent die rol van Calvyn se denke in die vroeë Gereformeerde belydenisskrifte. Breedweg gesproke stem die meeste geleerdes egter saam met die siening dat sy standpunte dikwels verlore geraak het, veral ten opsigte van die ware teenwoordigheid van Christus. Sien byvoorbeeld Jan Rohls, Die Gegenwart Jesu Christi im Abendmahl. Van besondere belang is die standpunte van belangrike Gereformeerde teoloë soos Hodge, wat Calvyn se eie lering oor die nagmaal as 'n teenstrydige vreemde element in Gereformeerde teologie beskou wat gedeeltelik uit Lutherse invloed afgelei is, en iemand soos Gerrit Hartvelt in Nederland wat in sy belangrike studie Verum Corpus. Een studie over een centraal hoofdstuk uit de Avondsmaalsleer van Calvijn tot soortgelyke gevolgtrekkings kom, naamlik dat die vreemde idee van Christus se lewegewende vlees wat in die hart van Calvyn se sienings gesetel is, 'n gevaarlike indringing in Gereformeerde teologie is.

56 "It is interesting to observe that while a belief in the real or true presence of Jesus Christ in the Lord's Supper is critical for all the traditional theological statements in the Reformed tradition regarding the sacrament, this fact is not at all well known among members of the Reformed Churches, including both clergy and laity. Many in the Reformed churches assume that the doctrine of the real presence of Jesus Christ is uniquely Roman Catholic and that it has never had a place in their own tradition," Shelton, "A theology of the Lord's Supper from the perspective of the Reformed tradition." Vir 'n beskrywing van ontwikkelings in Nederland gedurende die $20^{\text {ste }} \mathrm{eeu}$, sien Brinkman, "Het sacrament in de gereformeerde geloofsbeleving".

57 'n Nuttige sleutel tot so 'n benadering word in die heel laaste woorde van Gerrish in Grace and Gratitude gebied, 190: "It is not at all surprising that stalwart Reformed divines have sometimes been not merely puzzled but offended by Calvin's talk about the communication of Christ's life-giving flesh. They may choose to reject it as a perilous intrusion into Reformed theology and insist that Christ's body is life-giving only because it was crucified. But in so doing they should note that Calvin's view of 
noue verband tussen dié vyf prosesse onderling is, kan die verhale van al vyf hierdie ontwikkelings waarskynlik ook afsonderlik vertel word. In die Suid-Afrikaanse ervaring van apartheids-teologie en -ekklesiologie en die gevolglike stryd om sigbare eenheid van die kerk, het hierdie misverstand rondom Calvyn se standpunte oor die nagmaal sekerlik 'n sentrale rol gespeel. Die verhaal van apartheid was ook letterlik die verhaal van die nagmaal wat die pad byster geraak het. Die eintlik kritiese vraag is gevolglik of dit wel sinvol is om Calvyn se eucharistiese teologie as 'n belowende ekumeniese voorstel te sien terwyl groot dele van die Gereformeerde familie die eintlike hart van hierdie siening oor die teenwoordigheid van Christus reeds êrens langs die pad verloor het.

\section{BIBLIOGRAFIE}

Berkouwer, G C 1954. De sacramenten. Kampen: Kok.

Billings, J 2007. Calvin, participation, and the gift: The activity of believers in union with Christ. Oxford: Oxford University Press.

Birmele, A \& W Thönissen (Hrsg.) 2012. Johannes Calvin ökomenisch gelesen. Leipzig: Evangelische Verlagsanstalt.

Brinkman, M E 1992. "Het sacrament in de gereformeerde geloofsbeleving", in Brinkman, M E (red.), 100 Jaar Theologie. Kampen: Kok, 211-247.

Calvin, J 1848. Commentary on the Epistles to the Corinthians. Edinburgh: Calvin Translation Society.

the Lord's Supper was bound up with a total conception of what it means to be saved and of how the historical deed of Christ reaches out to the present. It is impossible to read Calvin's ideas on Baptism and Eucharist in their own historical context and not to notice that they were developed in part as a warning against what he took to be another peril: a mentality that reduces sacred signs to mere reminders, communion with Christ to beliefs about Christ, and the living body of the church to an association of likeminded individuals. Only a careful study of later Reformed history can show which has turned out to be the greater of the two perils. But this much, I think, can fairly be said in conclusion: even if the Calvinists have the greatest difficulty in expressing what exactly that something more is that they experience in the holy banquet, ecumenical theology will always have need of them to throw their weight in on Calvin's side of the Reformed boat," (my beklemtoning). Dit is leersaam dat hy afsluit dat dit in ekumeniese teologie vir Calviniste nodig sal wees om Calvyn se denke in hierdie opsig te volg. 
Calvin, J 1863. Institutes of the Christian Religion. Tr. H Beveridge. Edinburgh: T \& T Clark.

Calvin, J 1958. Tracts and Treatises, Volumes I-III. Grand Rapids: Eerdmans.

Campi, E \& R Reich 2009. Consensus Tigurinus. Heinrich Bullinger und Johannes Calvin über das Abendmahl. Zürich: Theologischer Verlag Zürich.

Davis, T J 1995. The clearest promises of God: The development of Calvin's Eucharistic teaching. New York: AMS Studies.

Davis, T J 2008. This is my body. The presence of Christ in Reformation thought. Grand Rapids: Baker.

Faber, E-M 2009. "Mutual connectedness as a gift and a task: On John Calvin's understanding of the church", in Hirzel, M E \& M Sallmann, (eds.), John Calvin's impact on church and society, 1509-2009. Grand Rapids: Eerdmans, 122-144.

Gamble, R C 2004. "Calvin's controversies", in The Cambridge Companion to John Calvin. Cambridge: Cambridge University Press, 188-206.

Gerrish, B A 1982. The old Protestantism and the new. Chicago: University of Chicago Press.

Gerrish, B A 1993. Grace and gratitude. The eucharistic theology of John Calvin. Eugene, OR: Wipf \& Stock.

Hartvelt G P 1960. Verum Corpus. Delft: W D Meinema.

Hunsinger, G 2008. The eucharist and ecumenism. Cambridge: Cambridge University Press.

Janse, W 2008a. “Sacramenten”, in Selderhuis, H J (red.), Calvijn. Handboek. Kampen: Kok, 387-397.

Janse, W 2008b. "Calvin's Eucharistic theology: Three dogma-historical observations", in Gerhuis, H J (ed.), Calvinus sacrarum literarum interpres. Göttingen: Vandenhoeck \& Ruprecht, 37-69.

Mathison, K A 2002. Given for you. Reclaiming Calvin's doctrine of the Lord's Supper. Phillipsburg: P\&R. 
Nijenhuis W 1972. "Calvin and the Augsburg Confession", in Ecclesia Reformata. Studies on the Reformation. III. Leiden: Brill, 97-114.

Oberman, H A 2003. The two reformations. New Haven: Yale.

Opitz, P 2009a. "Calvins Interpretation der Kirche als 'Gemeinschaft der Heiligen' als Herausforderung für Kirche und Gesellschaft", in Weinrich, M \& U Möller (Hrsg.), Calvin heute. Neukircher-Vluyn: Neukirchener Verlag, 225-242.

Opitz, P 2009b. Leben und Werk Johannes Calvins. Göttingen: Vandenhoeck \& Ruprecht.

Partee, C 2008. The theology of John Calvin. Louisville: Westminster John Knox.

Plasger, G 2008. Johannes Calvins Theologie - Eine Einführung. Göttingen: Vandenhoeck \& Ruprecht.

Rohls J 2005. “Geist und Zeichen”, in Korsch, D (Hrsg.), Die Gegenwart Jesu Christi im Abendmahl. Leipzig: Evangelische Verlagsanstalt, 51-78.

Rorem P E 1994. “The Consensus Tigurinus (1549): Did Calvin Compromise?”, in Calvinus Sacrae Scripturae Professor. Calvin as Confessor of Holy Scripture. Grand Rapids: Eerdmans, 72-90.

Shelton, R M 1998. "A theology of the Lord's Supper from the perspective of the Reformed tradition", in McKim, D K (ed.), Major Themes in the Reformed tradition. Eugene, OR: Wipf \& Stock, 259-270.

Steinmetz D C 1995. "Calvin and his Lutheran Critics", in Steinmetz, D C, Calvin in Context. Oxford: Oxford University Press, 172-186.

Tamburello, D E 1994. Union with Christ. John Calvin and the mysticism of St. Bernard. Louisville: Westminster John Knox.

Van de Beek, A 2008. God doet recht. Eschatologie als Christologie. Zoetermeer: Meinema.

Wandel, L P 2006. The Eucharist in the Reformation. Incarnation and Liturgy. Cambridge: Cambridge University Press. 
Welker, M 2000. What happens in holy communion? Grand Rapids: Eerdmans (oorspronklik: 2004. Was geht vor beim Abendmahl? Gütersloh: Gütersloher Verlagshaus).

Zachmann, R C 2008. “Communio cum Christo”, in Selderhuis, H J (red.), Calvijn. Handboek. Kampen: Kok, 409-417.

\section{KEY WORDS}

Calvin

Lord's Supper

Presence of Christ

Reformed views of sacrament

\section{TREFWOORDE}

Calvyn

Nagmaal

Teenwoordigheid van Christus

Gereformeerde sakramentsbeskouing

\section{KONTAKBESONDERHEDE}

Prof DJ Smit

Fakulteit Teologie

Privaatsak X1

7602 MATIELAND

Tel: 0218083258

E-pos: djs1@sun.ac.za 